SEFAD, 2016 (36): 351-366

ISSN: 1300-4921/e-ISSN: 2458-908X

DOI Number: http://dx.doi.org/10.21497/sefad.285244

\title{
HZ. FATIMA DESTANI
}

\author{
Dr. Perihan ÖLKER \\ Selçuk Üniversitesi Edebiyat Fakültesi \\ Türk Dili ve Edebiyatı Bölümü \\ pakkus@selcuk.edu.tr
}

\section{$\ddot{\mathbf{O z}}$}

Hz. Peygamberin kızı, Hz. Ali'nin eşi ve Hz. Hasan ile Hüseyin'in annesi Hz. Fatıma İslâm tarihinde önem kazanmış bir şahsiyettir. Ayrıca temiz ahlâkı, takva sahibi oluşu gibi nedenlerle de Müslüman kadınlara örnek teşkil etmiştir. Hz. Peygamberin ölümünden altı ay sonra $\mathrm{Hz}$. Fatıma'nın üzüntüye dayanamayıp öldüğü rivayet edilir. Çalışmamızın konusunu teşkil eden eserde Hz. Fatıma'nın babasının ölümüyle çektiği acı, öleceğini öğrenmesi üzerine arkada bırakacağı öksüzler (Hz. Hasan ve Hz. Hüseyin) için üzülüşü, çocuklarının Hz. Fatıma'nın ölümüne üzülüşü, Hz. Ali'nin eşi $\mathrm{Hz}$. Fatıma için yaktığı ağıt bütün derinliğiyle ve son derece sade bir dille yansitılmaktadır. Dini-tasavvufi eserlerin genelinde olduğu gibi bu eserin de Türkiye kütüphanelerinde pek çok yazma nüshası mevcuttur. Üzerinde çalıştığımız nüshalar Konya Koyunoğlu Şehir ve Müze Kütüphanesi yazmaları arasında 5905 ve 5906 arşiv numarasıyla kayıtlı olanlardır. 5905 Arşiv numaralı yazmada 3 Muharrem 1239 (9 Eylül 1823) tarihi açıç̧a temmet kaydı olarak verilmektedir. Çalışmamızın temelini teşkil eden nüshaların harekeli oluşu dudak uyumunu inceleme imkânını doğurmuştur. Buradan yola çıkarak da 5906 arşiv numaralı yazmanın 18. yüzyıldan itibaren istinsah edilmiş olabileceği anlaşılmaktadır. Eserin dili Eski Oğuz Türkçesinin tipik bir örneğidir ve anlaşıldığı kadarıyla telif hâli 15. yüzyıl ve sonrasına, istinsah hâli ise 18. yüzyıl ve sonrasına ait olmalıdır. Farklı nüshalar üzerinde Mehmet Mahfuz Söylemez'in, Muhammet Kuzubaş'ın ve Şaban Doğan'ın çalışmaları mevcuttur. Bu çalışmamızla Eski Oğuz Türkçesinin ve İslâmî Türk edebiyatının temsilcisi olan eserlerden birini ilim âlemine kazandırmayı amaçlamış bulunmaktayız. Bu doğrultuda ortaya konacak çalışmalar Türk dilinin tarihî seyrini ortaya sermesi açısından önemlidir.

Anahtar Kelimeler: Hz. Fatıma, Eski Oğuz Türkçesi, destan. 


\section{EPIC OF FATIMAH}

\section{Abstract}

Daughter of Prophet Muhammad, wife of Ali and mother of Hasan and Husayn, Fatimah was a very important person in the history of Islam. She is a role model to Muslim women with her morality and piousness. It is said that six months after the death of Prophet Muhammad, Fatimah died because of deep sorrow. In this piece of work, Fatimah's sorrow for her father's death, her sorrow and worry for her two children - Hasan and Husayn - upon learning that she would die, her two children's grief for their mother, and Ali's lament for his wife are profoundly reflected in a plain language. Like many religious and sufic work, there are many copies of this work in Turkish libraries. The copies we have worked with are the ones archived with the number of 5905 and 5906, among the manuscripts of Konya Koyunoğlu City and Museum Library. In the writing no. 5905, it is clearly written that the date of 3 Muharram 1239 (9th of September, 1823) was the completion date of the writing. The writings we have worked contained wovel points, and therefore we had the chance to examine labial harmony. With this information, it is understood that writing no. 5906 was copied beginning from 18th century. The work is a typical example of Old Oghuz Turkish language. The copyright form of the writing belongs to the 15th century and after, and the copied form belongs to the 18th century and after. There are studies of Mehmet Mahfuz Söylemez, Muhammet Kuzubaş and Şaban Doğan, on different copies. With this study, we aim to bring this representative work of Old Oghuz Turkish and Islamic Turkish literature in the world of science. Future studies in line with this purpose are very important to show the historical process of Turkish language.

Keywords: Fatimah, Old Oghuz Turkish, epic. 


\section{GíRiş}

Hz. Fatıma, İslâm tarihinde, Hz. Peygamberin kızı, Hz. Ali'nin eşi ve $\mathrm{Hz}$. Hasan ile Hüseyin'in annesi oluşu gibi nedenlerin yanı sıra temiz ahlâkı, takva sahibi oluşu yönüyle de Müslüman kadına örnek olmuştur. Hz. Peygamberin ölümünden altı ay sonra üzüntüsüne dayanamayıp öldüğü rivayet edilen $\mathrm{Hz}$. Fatıma, Klâsik Türk edebiyatında da ayrı bir değere hâizdir. Aruz vezniyle yazılmış destanlara tüm bu değerli vasıflarıyla konu edilmiştir:

Fatımatü'l-kübra, binti ebiha künyeleri ile de anılan $\mathrm{Hz}$. Fatıma beyaz ve parlak tenli oluşu nedeniyle Fatımatü'z-zehra; namuslu, faziletli kadın anlamiyla Betûl lakaplariyla da anilmıştır. Hatun-ı klyamet de vasıflarindandir. Hicretten on üç yil önce Mekke'de doğmuştur. Annesi Hatice'dir. 15 yaşında Ali ile evlenmiş, peygamber soyu onun çocuklariyla devam etmiştir. Hasan, Hüseyin, Muhsin, Ümmi Gülsüm, Zeynep adlarında beş çocuk annesidir. Fatıma akl, zekâsı, güzelliği, zühdü, takvası, güzel ahlâklı oluşu gibi pek çok olumlu özelliğiyle peygamberin özel sevgi ve ilgisini kazanmıştır. Fatıma birçok hadisin ravisidir. Hadise göre Meryem'den sonra gelen bütün kadınlardan üstündür. Akl, zeka ve dirayeti, din ve takvaya düşkünlügü, yetim ve yoksullara karşı merhameti hakkında pek çok anlatma vardır. Her şeyi ile babası ve eşine layık görülmüştür. Tefsirciler onun hakkında birkaç ayet nazil olduğunu kabul ederler. $\mathrm{Hz}$. Fatıma, $\mathrm{Hz}$. Hasan ve Hz. Hüseyin, kurretü'l-ayn ${ }^{1}$ (göz bebeği, göz sevinci, gönül açan) ifadesiyle şiirde iktibasa konu edilmişlerdir. Peygamberin ölümünden sonra hiç gülmediği onun hakkında anlatılan rivayetlerdendir. Babasına karşı beslediği sevgisi ve bağllı̆̆ı nedeniyle onun ölümünden altı ay sonra 24-29 yaşlarında öldüğüne inanılır (632) (Akkuş 2003: 439).

Hz. Fatıma'nın örnek gösterilen vasıfları İslâmî Türk edebiyatında da etkisini göstermiş, pek çok nüshasının bulunduğu destanlara konu edilmiştir. Destan kelimesini divan şairleri de kullanmış, aruz vezniyle yazdıkları manzum hikâyelere "dâstân" adını vermişlerdir (Albayrak 1993: 2). Destanda Hz. Ali, Hz. Hasan ve Hz. Hüseyin'e yer verilmesi eserin daha çok Alevi çevreye mensup edebiyat geleneği eseri kabul edilmesine neden olmuştur.

Hz. Fatıma'nın Hz. Peygamber'in kızı ve örnek Müslüman kadın oluşunun konu edinildiği Fatıma Destanı'nın Türkiye kütüphanelerinde pek çok yazma nüshası mevcuttur. Muhammet Kuzubaş Millî Kütüphane Yazmalar bölümünde 8624 kayıt numarasıyla yer alan nüsha üzerinde çalışmıştır. Eser Şerh-i Mevlid-i Şerif başlığını taşıyan bir bölümle başlar... Müellifin kaleme aldığı Şerh-i Mevlid-i Şerif yaprakların kopmasi sebebiyle eksiktir. Bu eksik manzumeden sonra Süleyman Çelebi'nin Vesiletü'n-Necâtından bölümler vardır. Daha sonra sirasıyla Destan-ı Veysel Karânî, Vefat-ı Hz. Fatıma, Vefat-ı Hz. İbrahim, Hikayet-i Gügercin ve Hikayet-i Geyik yer almaktadır (Kuzubaş 2008: 308). Eserin tarihi belli

${ }^{1}$ Kur'ân-1 Kerîm'de Furkan 25/74, Kasas 28/9, Secde 32/17 ayetlerinde geçen ifade divan şairlerince $\mathrm{Hz}$. Fatıma, Hz. Hasan ve $\mathrm{Hz}$. Hüseyin için kullanılmıştır. 
olmamakla birlikte dil ve imla özellikleri açısından Eski Anadolu Türkçesi dönemine ait olduğu belirtilmektedir. Yazmada Vefât-1 Fâtıma Razıyallahü 'Anha başlığını taşıyan bölümün 97 beyitten oluştuğunu ve mesnevi nazım şekliyle yazıldığını görüyoruz. Hz. Peygamberin vefatı sonrasında $\mathrm{Hz}$. Fatıma'nın içinde bulunduğu hüzün atmosferinin realist bir tasviriyle başlayan Vefât-ı Hz. Fâtıma bölümünün ilk beyitlerinde $\mathrm{Hz}$. Fâtıma'nın dilinden $\mathrm{Hz}$. Peygamber'e duyulan hasret dile getirilir. Ardından Hz. Fatıma'nın ömrünün son günleri, Hz. Hasan ve $\mathrm{Hz}$. Hüseyin ile konuşması ve vefatı anlatılır. Ayrıca bölümün sonuna doğru $\mathrm{Hz}$. Fatıma'nın yüceliğini anlatan Fâtıma'dur gelen redifli bir gazel eklenmiştir (Kuzubaş 2008: 309).

Şaban Doğan Hz. Fatıma destanının Bosna-Hersek Gazi Hüsrev Kütüphanesinde, Oxford Bodleian Kütüphanesi'nde, Vatikan Kütüphanesi'nde, Mısır Millî Kütüphanesi'nde, Mısır-Kahire Hidiv Kütüphanesi'nde, Millî Kütüphane'de, Konya Bölge Yazma Eserler Kütüphanesi'nde ve Millet Kütüphanesi'nde olmak üzere 14 nüshasını tespit etmiştir. Doğan'ın çalışmasına kaynaklık eden nüsha ise Millet Kütüphanesi Ali Emiri Manzum 1412 arşiv numarasıyla kayıtlı olandır. Eser 184 beyitten oluşmaktadır. Yedi varaktan müteşekkil eserin her sayfası on beş satırdır. 1491/1492 yılında Edirne Karabulut Mescidi İmamı Halil tarafından telif edilmiştir (Doğan 2012: 10). Ancak çalışılan nüsha istinsahtır.

Mehmet Mahfuz Söylemez'in hazırladığı Durmuş Topal nüshasında "Hazâ Destân-1 Fâtıma Radıyallahu 'Anha" başlığıyla 101 beyit mesnevi nazım şekliyle yazılmış bölümden sonra Fatımandur bu gelen redifli 10 dörtlük, ve arkasından 15 beyit daha devam eden mesnevi nazım şekliyle oluşturulmuştur. Söylemez'in çalışı̆̆ı yazmada Destân-1 Fâtıma'nın yanı sıra Destan-1 İbrahim Edhem, ve Destan-1 Hatun da yer almaktadır. On sekiz varaktan oluşan eserde her sayfa 15 satırdan oluşmaktadır.

Tespit edip üzerinde çalıştığımız nüshalar Konya Koyunoğlu Şehir ve Müze Kütüphanesi yazmaları arasında 5905 ve 5906 arşiv numarasıyla kayıtlıdır. 5905 arşiv numarasıyla kayıtlı olan eserin istinsah tarihi 3 Muharrem 1239 (9 Eylül 1823) şeklinde açıkça verilmektedir. "Hažā Destān-1 Fāṭıma Budur" başlı̆̆ı eserde yer almaktadır. Harekeli nesihle yazılmış olan eser 6 varaktan ibarettir ve hemen her sayfası 13 olmak üzere toplamda 131 satırdan oluşmaktadır. 5906 arşiv numarasıyla kayıtlı olan eserin ise istinsah tarihi belli değildir. 6 varaktan oluşan eserin başlığı "Fāț̣ma Ana Aḥvāli" olup her sayfanın belli bir düzene bağlı olmaksızın 12, 13, 14 ve 15 olmak üzere toplamda 134 satırdan oluştuğu görülmektedir. 5906 arşiv numaralı eser diğerine göre biraz daha yıpranmış ve yer yer yırtılmış vaziyettedir. Her iki nüshada da Hz. Ali'nin ağzından Hz. Peygambere hitaben söylenmiş konu olarak mersiye, nazım türü olarak murabba diyebileceğimiz "Fāṭımañdur bu gelen" redifli şiir de yer almaktadır. İki eser de remel bahrinin aruz vezninin fâilâtün/fâilâtün/fâilün vezniyle yazılmıştır. 


\section{ÇEVIRI YAZI ALFABESINE AKTARILMIŞ METIN}

\section{-5905 Arşiv Numaral1-}

\section{$1 \mathrm{~b}$}

\section{Haz̄ā Destān-ı Fāṭma Budur}

1 İşid imdi Fāṭmā aḥvālini / Kim Resūlden șoñra noldı ḥālini

2 Gice gündüz ag̉lamag̉a başladı / Kā’inātı țaglamag̉a başladı

3 Yemez içmez uyumazdı bir zamān / Şöyle kim hayretde ḳalmışdı hemān

4 Derdi vā ḥasreta vā firḳatā / Kanda gitdiñ ey baba vā veyletā

5 Ḳandasın ey şems-i tābān ḳandasın / Ruḥleri gül zülfi reyḥān ḳandasın

6 Firḳatüñ derdiyle uş yandum oda / Ey ḳamu dertlere dermān ḳandasın

7 Ḥasretiñden ḳana boyandı ciger / Oda yandı ins-ile cān ḳandasın

8 Söyleşürken iki kimse görse ol / İder ${ }^{2}$ idi anlara ḳanı Resūl

9 Yerüñ altında yata ol bedr-i tām / Ne revādur söyleşürsiz siz kelām

10 Böyle olur ḳanı hürmet ḳanı cehd / Kanı dostluk ḳanı șoḥbet ḳanı 'ahd

11 Ol degil midi size dā'im 'ațūf / Ol degil midi bize her dem Ra' ûf

\section{2a}

1 Ey yürek yan yüzi güneş māh-1 cūm / Kara ḳara ḳana ḳana şāh-1 cūm³

2 Böyle diyüp ag̉ladı ol nigār / Gözlerinden yaş yerine ḳan iner

3 Bir gün aṣhāb bir yire cem' oldılar / Yā 'Ali Fāṭmaya söyle didiler

4 Gice gündüz dā’im ag̉lar ol nigār / Biz de anuñçün idemezüz ḳarār

5 Ag̀lamag̀-1la ele girse Resūl / Vü yahūd cān virmege ol pür-uṣūl

6 Aglayup vireydüñ cānımuz / Tek ele girseydi ol Sultānımuz

7 Leyki bu hükm-i Hudādur nidelüm / Aña rāżı oluban șabr idelüm

8 Vardı Fāṭmaya didi ol-dem 'Alī / Fāṭıma ag̉layu didi yā velī

9 Yerüñ altında yata Şāh-1 Resūl / Agglayup nice olmayam ben melūl

10 Ah idüp bir kerre ol düşdi yere / Yoġıdı 'aḳlı ki kendüñi dire

11 Nice vaḳtden șoñra ol hayrü'l-betūl / Kalḳdı yerinden olup gāyet melūl

12 Didi kim diñle beni sen yā 'Alī / Gel kerem ḳıl var ḳubbeye yā velī

13 Anda baña bir gömelte yapıvir / İçine dahı anuñ gül șaçıvir

\section{2b}

1 Adın anuñ beyt-i ahzen ḳoyalum / Anda varup ḳanlu yaş ag̉layalum

2 Sözüni ḳıldı ḳabūl anuñ 'Alī / Vardı bir ev yapdı anda ol velī 
3 Her șabāḥ anda varup aglarıdı / Nevha ḳılup cigerin țaglanıdı

4 Tā şuña dek kim demişidi Resūl / Altı aydan șoñra ey hayra'l-betūl

5 Emr-i Haḳdur baña sen gelseñ gerek / Benüm-ile tā ebed olsañ gerek

6 Çünki va'de yetdi bir gün ol nigār / Kabrine vardı Resūlüñ ḳıldı zār 7 İştiyāḳım geçdi ḥadden ziyāde didi ol / Yaḳdı hicriñ nārı cānım yā Resūl

8 Niceye-dek bunda ben șabr ideyim/Kendüzüme nice bir cebr ideyim 9 Ey dırīìā zārı nice gizleyem / Vaḳtimi ben yā nicesi gözleyem

10 Firḳatünüñ baḥrine ben düşmişem / Hasretiniñ oduna ben țüşmişem

11 Zaḥmetü miḥnetlerüm çoḳdur benüm / Dahı hergīz tạḳatüm yoḳdur benüm

12 Uş cerāḥat oldı yarañ başına / Nūrı gitdi gözlerimiñ yaşıña

13 Uş benevşe gibi ḳaddim oldı hām / İşbu derde nice olasıdur 'ām

\section{3a}

1 Belüm inceldi benim oldum hilāl / Gitdi şādī göñlime erdi melāl 2 Furḳat ag̉usın țolu țolu ḳadeh / Nūş ḳıldım nice olam ben ferah 3 Çün habīibüm menziliñ olsun turāb/Bu cihān olsun harāb ender harāb 4 Katı efgān eyleyüben dökdi yaş / Eriyüp șu oldı anda țag u țaş 5 Ditredi ḳabri Ḥabībüñ ol zamān / Düşdi ḳabir üstine ag̉lar hemān 6 Ḳabr içinden Mușțafā ve Müctebā / Didi kim ey nūr-1 'aynī merḥabā 7 Katı müştāḳam didi ḳızum saña / Va'de yetdi gelisersin sen baña 8 Şāz oluban țurdı yerinden revān / Vardı eve ol-dem içinde hemān 9 Başladı evüñ içre devşürmege / Kendüzüni hem Ḥaḳa ḳavşurmaġa 10 Gördiler anı Hüseyn-ile Ḥasan / Didiler ey ana bugün n'oldı sen 11 Böyle ta'cīl mașlahat nedür size / Luṭ̂ññzdan vir haber ana bize 12 Fāṭma bu sözi çünki diñledi / Derd-ile āh eyleyüben iñledi 13 4 / Yanına geldi Hüseyn-ile Hasan

\section{3b}

1 Birin aldı bir dizine ol ana / Bir dizine birin aldı hem yine

2 Öpdi gözlerini sürdi yüzini / Yüzüne sürdi olarıñ yüzüni 3 Baḳıban yüzlerine çok ag̉ladı / Yüregüñ țaşdan degilse ag̉ladı 4 Didi ey cānım og̉ullar nideyim / Kanḳı derdimi size şerh ideyim 5 Va'de yetdi biliñüz bu dem hemān / Dedeñüz gel didi uş ol dem revān 6 Uş ecel irdi baña vā ḥasretā / Sizden ayruluram vā furḳatā 
7 Ey 'aceb kime 1ṣmarlayam sizi / Size müşfiḳ mihribān ola sözi 8 Vey 'aceb kim yuyısar başuñızı / Yā siziñ kim siliser yaşuñuzı 9 Șaçuñuzı kim țarayısar siziñ / Gözünüz kim sürmeleyiser siziñ 10 Ya giyecegünüzi kim yuyısar / Öñünüze yeyicek kim ḳoyısar 11 'Ömrimüñ āhir güni durur bugün / Size ḳurbān olsun uş cānım bugün 12 Hem yuyayum bugün başlarıñuzı / Ṭarayayım güzel șaçlarıñuzı 13 Ah idüp țurdı yerinden aglayu /Furḳat odına........ ${ }^{5}$

\section{$4 a$}

1 Başladı yudı țaradı başların / Dökdü gözünden ḳanlu yaşların 2 Ṭaşradan ol-dem girüp geldi 'Alī / Fāṭmānuñ gördi kim işde eli 3 Hīç 'Alīye Fāṭıma söylemedi / Baḳıbanı iltifāt eylemedi 4 Didi kim yā Fāṭma n'oldı saña / Kim ezelki gibi bakmazsıñ baña 5 Baña niçün söylemezsin ey hịlāl / İdivir ${ }^{6}$ baña ne durur işbu ḥāl 6 Fāṭma eydür yā 'Ali diñle beni / Ne sebebden eyledüm diñle bunı 7 Va'de itmişdi babam ol-dem baña / Yetdi ol va'de bugün nidem saña 8 Çün babam gel didi oldum revān / Allāha ıṣmarladım sizi hemān 9 Sen esen ḳal ben göneldim giderem / Saña Ḥüseynle Ḥasan ı̣̣marlaram $10 \mathrm{Bu}$ iki körpe ḳuzularum i cān / Hoşca țutğl dilegüm budur hemān 11 İşbu sözleri işitdi çün 'Alī / Ah idüp ag̉ladı anda ol velí 12 Geçdi ol gün ahşām oldı ol nigār / Didi kim ey Ḩālıḳ-ı perverdigār 13 Saña ṣığındım İlāhī ḥālimi / Virmege āsān ḳılıvir cānımı

\section{4b}

1 Böyle deyüben [hemān?] ah eyledi / Cānını teslīm-i Allāh eyledi 2 Ahşāmla yatsu arasında vefāt / Eyledi sırrı binti kāināt 3 Ḳoḳdı anda misk-i 'anberle gülāb / Ditredi üstüne anuñ āfitāb 4 Zāhir oldı ol eviñ içinde nūr / Ṭoldı anuñ içi ervāḥ-ile hūr 5 Hem Hadīce rūḥ-1 Havvā rūḥıla / Rūḥ-1 Meryem Āyişe rūḥı bile 6 Sāre Hācer rūḥı hāạı̣r oldılar / Ol nigārı üstüne ag̉laşdılar 7 Ḥāẓır oldı enbiyā ervāḥı hem / Z̄ì mübārek sā'at u ḳutlu ḳadem 8 Yüzi tāze gül gibi yatmışıdı / İçi țaşı nūra hem batmışıdı 9 Üstüne varup 'Alī eyledi yas / Ḳanlu yaş dökdi gözinden țas țas 10 Didi ey cānım og̉ullar geliñüz / Anañuz gitmiş cihāndan biliñüz 11 Geldi yanına Ḥüseyin-ile Ḥasan / Gördiler gitmiş cihāndan ol hasen 
$12 \mathrm{Ol}$ ikisi șarmaşup ag̉laşdılar / Ḥasretiyle ḳanlu yaşlar șaçdılar

13 Didiler bu iş durur ġāyet 'acīb / Bir 'aceb durur ü ḳalmışız garīib

\section{$5 \mathbf{a}$}

1 Kalbimüze düşdi furḳat ḳoḳusı / Geldi bize hem yetimlik ḳoḳusı

2 Dedemüz getdi vü biz ḳaldıḳ hazīn / Sende getdüñ bize kim olsun emīn

3 Noldı nergīs gözlerüñ yumduñ ana / Furḳat odına bizi yaḳduñ ana

4 Hasretiyle yaralanmış anamuz / Furḳatıyla yaralanmış anamuz

5 Baġrı başlı gözi yaşlu anamuz / Şems yüzlü māh ḳaşlu anamuz

6 Gözi yaşına ġarḳı varmış anamuz / Başı cānı Şāha virmiş anamuz

7 Noldı saña ḳatı yanmışsın bugün / Urduñ ana yüregümüze dügün ${ }^{7}$

8 Göz yaşıyla yer yüzin ıșladılar / Analarınuñ yașın yașladılar

9 Er ü 'avrat bir yere cem' oldılar / Ḥasreti odına yanup şemi' oldılar

10 Halvet itdiler evi ol-dem hemān / Yumaga başladılar anı ey cān

11 Misk-ile 'anber buhūrlar itdiler / Agglaşuban üstüne șaf țutdılar

12 Yuyubanı șardılar aña kefen / Katına geldi Ḥüseyin-ile Hasan

13 İkisi șarmaşuban ögrişdiler / Üstüne analarınıñ düşdiler

\section{$\mathbf{5 b}$}

1 Öpdiler yüzini efḡān itdiler / Ag̉laşuban göz yaşını ḳan itdiler

2 Ol güzeller şāhı açdı gözlerin / Her yirin ohşadı öpdi yüzlerin

3 Gögsine baṣdı ve kucdı anları / Yaḳdı hasret odıyıla cānları

4 Bir ḳıyāmet ḳopdı o gice ey yār / K'andan oldı biñ ḳıāmet āşikār

5 Ey niceler anda mecnūn oldılar / Vey niceler zār u mahzūn oldılar

6 Ditredi 'arş-1la kürsī nüh felek / Ag̉ladı anuñ-içün cümle melek

7 Geldi Ḥaḳdan bir nidā kim yā 'Alī / Kaldur üstünden oları yā velī

8 Pāre pāre olmasun çarh-1 felek / Yanmasun hasret odına her melek

9 Anları ḳaldırdı üstinden revān / Oldılar meşgùul namāzına hemān

10 Didi ol-demde Ebū Bekre 'Alī / Siz ḳllıviriñ namāzın yā velī

11 Ḳıldılar anıñ namāzın ol gice / Kudretini gör Hakuñ diñle nice

12 Pes cenāzeyle anı götürdiler/ Babasınuñ ḳabrine yetürdiler

13 Illteler ol-dem Resūlıñ yanına / Ḳıldılar medḥ-i denālar cānına

\section{6a}

1 Başlayup işbu sözi didi 'Alī / Âh u vāh üniyile yaḳdı ili 
2 Ol yamalu eski geyen Fāṭımañdur bu gelen / Hem yalıncaḳlıga doyan Fāṭımañdur bu gelen

3 El degirmenin çeküp arpa etmegiyle beslenen / Cevr-i faḳrla büyüyen Fāṭımañdur bu gelen

4 Ḥasretüñ derdi șarardup beñzini tag̉yīr iden / Hicriñ odunı cānına ḳoyan Fāṭımañdur bu gelen

5 Boynını ege ḳoyup kendüzini alçaḳ țutan / Ol yüñce ḳadrüñe țoyan Fāṭımañdur bu gelen

6 Şol cemāliñ şem'ine pervāne olup bir zamān / Hiżmetüñde yüz sürüben Fāṭmañdur bu gelen

7 Her ḳaçan gamda keder irse mübārek ḳalbüñe / Maḥv idüp anı yuyan Fāṭmañdur bu gelen

8 Vușlatuñı cān u göñülden teşevvuk eyleyen / Ġurbet eyyāmına doyan Fāṭımañdur bu gelen

9 Ümmetüñ-içün şefā'at hüccetini șaḳlayup / Anlaruñ kaydını ${ }^{8}$ yiyen Fāṭımañdur bu gelen

10 Mevtini 'ilme'l-yaḳin bilüp yaraġın eyleyen / Hem yetīmleri döke ḳoyan Fāṭmañdur bu gelen

11 Bunuñ-1la vā'de idüp gitmişidüñ yā Resūl / Șabr idüp ol güne göyen Fāṭmañdur bu gelen

12 Uşda ardımca gelürsin demişidiñ ag̉lama / Avınup ol söze iviben Fātımañdur bu gelen

13 İnțizār çeküben arzū ḳılar-idüñ bunı sen / Muştuluḳdur imdi uyan ol Fāṭmañdur bu gelen

\section{6b}

1 Ḳolların çıḳardı ḳabrinden hemān / Aldı elinden 'Alīniñ onı zamān

2 Yanına aldı nevāziş eyledi / Hoş mısın ḳızım șafā geldiñ dedi

3 Ṭurmañ imdi var-iken sizde ḥayāt / Eṣ-șalavat deñ ile ḳable'l-memāt

4 Temmetü'l-kitābı bi-‘avnillahi'l-Meliki'l-Vehhāb

\section{-5906 Arşiv Numaralı-}

\section{2a}

\section{Fāṭma Ana Aḥvāli}

1 İşit imdi Fāṭma aḥvālini / Kim Resūlden șoñra n'oldı hālini

2 Gice gündüz ag̉lamaġa başladı / Kāinātı țaglamag̉a başladı

3 Yimez içmez uyumazdı bir zamān / Şöyle kim hayretde ḳalmışdı hemān

4 Didi kim vā hasretā vā firḳatā / N'ideyin ben ey ata vā veyletā 
5 Kandasın ey māh-1 tābān ḳandasın / Gül yüzi vü zülfi reyḥān ḳandasın 6 Furkatüñ odıyla ben yandum oda / Ey ḳamu dertlere dermān ḳandasın 7 Söyleşir bir yerde kimse görse ol / Anlara iderdi ${ }^{9}$ kim ḳanı Resūl 8 Böyle olur ḳanı hürmet ḳanı 'ahd / Kanı dostluk ḳanı șoḥbet ḳanı 'ahd 9 Ol degil midi bize dā'im 'ațūf / Ol degil midi bize dā'im Ra'uf 10 Ey yürek yan yüzi güneş māh-içün / Kana ḳana yana yana şāh-içün 11 Böyle diyüp dā'im ag̉lar ol nigār / Gözlerinden yaş akardı seyl-vār 12 Bir gün aṣhāb bir yire cem' oldılar / Yā 'Alī diñle sözümüz didiler 2b

1 Var kerem eyle digil gül-'izār / Gice gündüz ag̉lamasın zār zār 2 Agglamaḳla ele girseydi Resūl / Yāḥud ol cān virmek-ile pür uṣūl 3 Ag̉layuban vireyidik bize cānımuz / Tek ele gireyidi cānānımuz 4 Leyki bu hükm-i Hudādur nidelüm / Buña rāżı olalum șabr idelüm 5 Ḳıldı bu söz didi ol demde 'Alī / Fāṭ̂ma ag̉adı didi yā velī 6 Yeriñ altında yatur şāh-1 Resūl / Nice ag̉lamayam olmayam melūl 7 Ah idüben ol-dahı düşdi yere / Yoğudı 'aḳlı ki kendüsi dire 8 Nice vaḳtden șoñra ol hayrü'l-betūl / Kalḳdı yerinden olup gāàet melūl 9 Fātı̣ma didi ki diñle yā 'Alī / Kabrine varg̉ıl Resūlüñ yā velī 10 Tā ki anda bir gömelet yapıvir / İçine anıñ dahı gül șaçıvir 11 Adın anıñ beyt-i āḥzen ḳoyalım / Anda vardum ḳanlu yaş aglayalum 12 Sözini ḳıldı ḳabūl ol-dem 'Alī / Vardı bir ev yapdı anda ol velī 13 Her șabāḥ vardı anda ol nigār / Nevha idüp ag̉larıdı zār zār 14 Tā ki aña dimişidi ol Resūl / Altı aydan șoñra ol ḩayrü'l-betūl 15 Emr-i Haḳdur baña sen gelseñ gerek / Hem benümle tā ebed olsañ gerek

\section{3a}

1 Çünki va'de yetdi bir gün ol nigār / Kabrine vardı Resūlüñ ḳıldı zār 2 İştiyāḳım geçdi hadden didi ol / Yaḳdı cānım nār-ı hicret yā Resūl 3 Ey dirīìā niceyi șabr ideyin / Kendi özime nice șabr ideyin 4 Furḳatünüñ bahrine ben düşmüşem / Ḥasretiñ nārına ben tutuşmuşam

5 Zaḥmetüm miḥnetlerüm çoḳdur benüm / Daḩı hergiz țaḳātüm yoḳdur benüm

6 Bu cerāḥat oldı yürek baş-1la / Gözlerimiñ nūrı gitdi yaş-ıla $7 \mathrm{Ol}$ benefşe gibi ḳaddüm oldı hem / İşbu derde nice olayıdur em 
8 Tenüm incindi ḳatı oldum hilāl / Gitdi şādı̄i cānıma irdi melāl 9 Furḳat ag̉usın țolu țolu ḳadeh / Nūş ḳıldım nice olam ferah 10 Çün Habībiñ menzili oldı türāb / Bu cihān olsun harāb-ender-harāb

11 Katı efgāan eyleyüp hem dökdi yaş / Eriyüp șu ola yazdı anda țaş

12 Ditredi beyt-i Resūl-i Kirdigār / Düşdi ḳabri üstine ol-dem nigār

13 Kabr içinden Mușțafā vü Müctebā / Didi kim ey nūr-1 'aynı merḥabā 14 Katı müştākam ciger-gūşem saña / Va'de yetdi gelisersin sen baña

\section{3b}

1 Şāz oluban țurdı yerinden hemān / Vardı girdi evine ol-dem hemān 2 Başladı kendi özün ḳoşurmaḳa / Hem eviñ için țaşın devşirmege 3 Gördiler anı Ḥüseyinle Ḥasan / Didiler ey ana nolduñ bugün sen 4 Böyle ta ccîl mașlaḥat nedür size / Luțiñuzdan bir haber virüñ bize 5 [Bu] sözi çünkim bulardan diñledi / Derd-ile bir ah idüben iñledi 6 [Geli]ñ oguullar didi ol nūr-1 'ayn / Yanına geldi Hüseyn-ile Ḥasan 7 Birin aldı bir dizine ol ana / Birin aldı bir dizine hem yine 8 [Öp]di gözlerini sürdi yüzini / Yüzüne sürdi evlādıñ yüzini 9 [Yüz]lerine baḳdı ve çoḳ ag̉ladı / Yüregüñ țaşdan degilse agladı 10 [Did]i ey cānım og̉ullar nideyin / Kanḳı derdimi size şerḥ ideyin 11 [Va']de yetdi biliñüz bu dem hemān / Dedeñüz geldi ḥoş ol-dem revān 12 [Uş] ecel irdi baña vā ḥasretā / Sizden ayrı düşerem vā furḳatā 13 [Ey] 'aceb kime 1ṣmarlayam sizi / Size müşfik mihribānım ben ḳuzı

\section{$4 a$}

1 Tozlanıcaḳ başıñuz kim yuyusar / Ag̉layıcaḳ yaşıñuz kim siliser 2 Gözüñüz kim sürmeleyiser siziñ / 'Ömrümüñ șoñ günidür bu gün benim 3 Yuyayın bugün siziñ șaçlarıñuz / Hem țarayayım güzel başları̃nuz 4 Ah idüp țurdı yerinden aglayup / Firḳat odıyla yüregin țaglayup 5 Başları yudı țaradı șaçların / Dökdi iki gözi ḳanlı yaşların $6 \mathrm{Bu}$ aralıḳda çıḳa geldi 'Alī / Fāṭımanuñ gördi [kim] işde eli 7 Didi kim yā Fāṭıma noldı saña / Niçün ag̉larsın haber virgil baña 8 Baña niçün söylemezsin ey hilāl / Diyüvirgil baña n'oldı işbu hāal 9 Dir 'Alīye Fāṭma diñle bini / Bāḳi ḳılsun Ḥaḳ bu dünyāda seni 10 Va'ad itmişdi babam ol-dem baña / Oldı ol ne gün ne deyem ben saña 11 Çün baban gel didi pes oldum revān / Allāha ıṣmarladum sizi hemān 12 Sen esen ḳal ben gömüldüm giderem / Saña Ḥasan Ḥüseyin ıṣmarlaram 


\section{$4 b$}

1 [B]u iki körpe ḳuzılarım hemān / Ḥoşça țutḳıl dilegim budur iy cān 2 Gözlerinüñ yaşını aḳıtmaġıl / Boynun egüp yollara baḳıtmaġıl 3 İşbu sözleri işitdi çün 'Alī / Ah idüp ag̉ladı anda ol veli 4 [Geç]di ol gün aḥşam oldı ol velī / Didi kim iy Ḩālıḳ u Perverdigār 5 Saña ṣığındım İlāhī hālimi / Virmege āsān idivir cānımı 6 Ahşamla yatsu arasında vefāt / Eyledi ol binti sırrı kāināt 7 Koḷdı ol-dem misk-i 'anberle gülāb / Ditredi üstine anıñ āfitāb 8 Z̄âhir oldı ol evüñ içinde nūr / Ṭoldı ervāḥ-ile anuñ içi hūr 9 Hem Hadīce nūrı Havvā nūr-1la / Rūḥ-1 Meryem Āsiye rūḥ̂-y-1la 10 Sāre Hācer rūḥu zāhir oldılar / Ol nigārıñ üstine ag̉laşdılar 11 Ḥāżır oldı enbiyā ervāḥı hem / Żī-sa‘ādet oldı hem ḳutlu ḳadem 12 Yüzi ol güller gibi yatmış-ıdı / İçi țaşı nūra hem batmış-ıdı

\section{$5 \mathbf{a}$}

1 Üstine vardı 'Alī eyledi yas / Kanlu yaş dökdi gözünden țas [țas]

2 Didi ey cānım og̉ullar biliñüz / Anañuz gitmiş cihāndan geliñüz 3 Geldi yanına Ḥüseyn-ile Ḥasan / Gördiler gitmiş cihāndan ol ḥasen $4 \mathrm{Ol}$ ikisi șarmaşup ag̉laşdılar / Hasretiyle ḳanlu yaşlar șaçdılar 5 Didiler bu ne işdür gāayet 'aceb / Bir 'acebdür ḳalmışuz ${ }^{10}$ kim garāib 6 Ḳalbimize düşdi furḳat ḳoḳusı / Geldi bize hem yetīmlik ḳoḳusı 7 Dedemüz gitdi ve biz ḳaldı̣ yetīm / Sen de gitdiñ bize kim olur emīn $8 \mathrm{Ne}$ oldı nergis gözleriñ yumduñ / Ana furḳat oduna bizi yaḳdın 9 Hasretiyle yaralanmıs anamuz / Furḳatıyla yaralanmış anamuz 10 Göz yaşıyla gözleriñ ıṣladılar / Analarıñ yasını yașladılar

11 Er ü 'avrat ol gice cem' oldılar / Hasret odına yanup şem' oldılar 12 Halvet itdiler anı ol-dem revān / Yumaġa meşgūl oldılar hemān 13 [Misk] ü 'anberle buhūrlar itdiler / Ag̉laşuban üstüne șagu țutdılar

\section{$\mathbf{5 b}$}

1 [Yu]dılar anı ve șardılar kefen / Yanına geldi Ḥüseyn-ile Hasan 2 [İkisi] șarmaşup bögrişdiler / Üstine analarınuñ düşdiler 3 Bag̣nı başlu gözi yaşlu anamuz / Başı cānı garḳa virmiş anamuz 4 Öpdiler yüzini efḡān itdiler / Ag̉ladılar yaşların ḳan itdiler $5 \mathrm{Ol}$ güzeller şāhı açdı gözlerin / Her birin ohş̧adı öpdi yüzlerin 
6 Bağrına baṣdı ve ḳuçdı bunları / Yaḳdı ḥasret odıyla bunları 7 Bir ḳıāmet ḳopdı ol gice ey yār / Bir ḳıyāmet oldı anda āşikār 8 Ey niceler anda mecnūn oldılar / Ey niceler anda maḥūn oldılar 9 Ditredi hem 'arş-1la kürsī felek / Anıñ içün agladı cümle melek 10 Geldi Ḥaḳdan bir nidā kim yā 'Alī / Kaldır üstünden buları yā velī

11 [Pā]re pāre olmasun çarh u felek / Yanmasun hasret odına hem melek 12 Anları ḳaldırdı üstünden revān / Oldılar meşḡūl namāzına hemān

13 [Ḳıldılar] anıñ namāzın ol gice / Ḳudret-i Hakḳı görüñ diñleñ nice

\section{$6 \mathbf{a}$}

1 Eletdiler ol-dem Resūl yanına / Kim ulaşdırdılar anı cānına

2 Dilediler 'ādet üzre hem anı / Kabrine ḳoyalar ol nāzik teni

3 Pes cenāzeyle anı götürdiler / Tā Resūlüñ kabrine yetürdiler

4 Pes selām dirüm 'Alī yā șafā / Didi geldi Fāṭıma yā Muṣțafā

$5 \mathrm{Ol}$ 'ālì eski giyen Fāṭmañdur bu gelen

6 Ol yalıncıḳlıga doyan Fāṭmañdur bu gelen

7 El degirmenin çeküp arpa unılla bislenen

8 Cevr-i faḳr-ıla büyüyen Fāțmañdur bu gelen

9 Hasretüñ derdi șarardup beñzini tag̀yīr iden

10 Hicr odı cānına ḳoyan Fāṭımañdur bu gelen

11 Vașluñı cān-1 gönülden teşevvuk eyleyen

12 Ġurbet eyyāmına doyan Fāṭmañdur bu gelen

\section{6b}

1 Her ḳaçan gamdan gubar irse münevver ḳalbine

2 Mahv idüp anı yuyan Fāṭımañdur bu gelen

3 Şol cemāliñ şem 'ine pervāne olup her zamān

4 Hizizmetiñde yüz sürüyen Fāṭmañdur bu gelen

5 Gitdigiñde buña va'de eylemişdüñ her zamān

6 Șabr idüp ol güne göyen Fāṭmañdur bu gelen

7 Mevtini 'ilme'l-yaḳin bilüp yaragin eyleyen

8 Ol yetīmler döke ḳoyan Fāṭmañdur bu gelen

9 İntizār çeküben arzū ḳılur-iken bu seni

10 Muştuluḳ imdi țur uyan Fāṭmañdur bu gelen

11 Gördiler faḥr-1 cihān ol șafā / Mușțafā vü Müctebā vü Murtaża

12 Ol mübārek ellerin ol-dem hemān / Kabrüñ içinden çıkardı nāgihān

13 Aldı elinden 'Alīnüñ Muștafāa / Kaldı hayretde 'Aliyyü'l-Murtażā 


\section{7a}

1 Çünki Resūl aldı ol-dem yanına / Ḳıldılar medḥ ü Senālar cānına

2 Ḳanı cismi ḳodı ol hayrü'l-beḳā / İtdi menzil milkiñi dārü'l-beḳā

3 Bunda olugör beḳā biñ yıl saña / Çün eriserdür yine āhir fenā

4 Çünki gitdi ehl-i beyt-i Muṣțafā / Gördiler bunlar belāda çoḳ cefā

5 Irag itme yā Rab anlardan bizi / Anlar-1la hasşr it cümlemüzi

Āmīn āmīn āmīn

Temmet

\section{SONUÇ}

İki nüshanın da istinsah olduğu söz varlığı ve harekelendirme esasına göre anlaşılmaktadır. 5905 arşiv numaralı yazma eserin son sayfasında 3 Muharrem 1239 (9 Eylül 1823) tarihi açıkça kaydedilmiştir. 5906 numaralı yazma eserde herhangi bir tarih yer almamakla birlikte harekelendirme sistemine bakıldığında yer yer dudak uyumunun gerçekleştiği örnekler karşımıza çıkmaktadır. Bu doğrultuda bu yazmanın hiç değilse 18. yüzyıl ve sonrasına ait olduğu kesinlik kazanmaktadır ${ }^{11}$. Hareke sistemi ve kelime hazinesi bize müstensihlerin eserin özgün hâline sadık kalmak için çaba sarfettiği ancak dönemin diline ve imlasına kayıtsız kalamadıklarını göstermektedir. Aşağıdaki bazı örnekler -sayıları çoğaltılabilir- dudak uyumundan yola çıkarak eserlerin en azından 18. yüzyıl ve sonrasına ait olduğunu ispatlamaktadır:

İștiyāḳım geçdi hadden ziyāde didi ol / Yaḳdı hicriñ nārı cānım yā Resūl (5905 2b/7) $2 b / 13)$

Uş benevşe gibi kaddim oldı hām / İşbu derde nice olasıdur 'ām (5905, $5 b / 13)$

[Ḳıldılar] anıñ namāzın ol gice / Ḳudret-i Ḥaḳkı görüñ diñleñ nice (5906, 4b/9) Üstüne varup 'Alī eyledi yas / Kanlu yaş dökdi gözinden țas țas (5905,

Agglayuban vireyidik bize cānımuz / Tek ele gireyidi cānānımuz (5906 2b/3)

Her iki nüshada da di-/de-ve söyle- fiilleri kullanılırken eyt- (söyle-) fiilinin it- şeklinde sadece üç kez kullanılmış olması söz varlığı açısından eserin 18. yüzyıl ve sonrasında istinsah edildiğine dair bir delil olmakla birlikte özgün şeklinin de 15. yüzyıl ve sonrasında yazılmıs olabileceğine işaret etmektedir.

\footnotetext{
11 Osmanlı Türkçesi döneminde dudak uyumu ile ilgili olarak daha ayrıntılı bilgi için bk. KARTALLIOĞLU, Yavuz (2008). "Osmanlı Türkçesindeki Ekler Dudak Uyumuna Göre Nasıl Okunmalıdır?”. Turkish Studies 3 (6): 449-470; KARTALLIOĞLU, Yavuz (2011). Klasik Osmanlı Türkçesinde Eklerin Ses Düzeni (16, 17 ve 18. Yüzyıllar). Ankara: TDK Yay.
} 
Söyleşürken iki kimse görse ol / İder idi anlara ḳanı Resūl (5905 1b/8)

Baña niçün söylemezsin ey hịiāl / İdivir baña ne durur işbu hāal (5905 4a/5) $2 \mathrm{a} / 7)$

Söyleşir bir yerde kimse görse ol / Anlara iderdi kim ḳanı Resūl (5906

Eserin dilinin son derece sade, halk ağzına yakın ve süslü üsluptan uzak olduğu görülmektedir. Nüshaların çeviri yazı alfabesiyle aktarılmış şekli yaptığımız araştırma ve inceleme doğrultusunda ortaya konmuştur.

\section{SUMMARY}

Daughter of Prophet Muhammad, wife of Ali and mother of Hasan and Husayn, Fatimah was a very important person in the history of Islam. She is a role model to Muslim women with her morality and piousness. It is said that six months after the death of Prophet Muhammad, Fatimah died because of deep sorrow. In this piece of work, Fatimah's sorrow for her father's death, her sorrow and worry for her two children - Hasan and Husayn - upon learning that she would die, her two children's grief for their mother, and Ali's lament for his wife are profoundly reflected in a plain language. Like many religious and sufic work, there are many copies of this work in Turkish libraries. The copies we have worked with are the ones archived with the number of 5905 and 5906, among the manuscripts of Konya Koyunoğlu City and Museum Library. In the writing no. 5905 , it is clearly written that the date of 3 Muharram 1239 (9th of September, 1823) was the completion date of the writing. The writings we have worked contained wovel points, and therefore we had the chance to examine labial harmony. With this information, it is understood that writing no. 5906 was copied beginning from 18th century. The work is a typical example of Old Oghuz Turkish language. The copyright form of the writing belongs to the 15th century and after, and the copied form belongs to the 18th century and after. There are studies of Mehmet Mahfuz Söylemez, Muhammet Kuzubaş and Şaban Doğan, on different copies. With this study, we aim to bring this representative work of Old Oghuz Turkish and Islamic Turkish literature in the world of science. Future studies in line with this purpose are very important to show the historical process of Turkish language. 


\section{KAYNAKÇA}

AKKUŞ, Metin (2003). "Fatıma". Türk Dünyası Ortak Edebiyatı, Türk Dünyası Edebiyat Kavramları ve Terimleri Ansiklopedik Sözlüğü. C. 2. Ankara: Atatürk Kültür Merkezi Başkanlığı Yay. 439-440.

ALBAYRAK, Nurettin (1993). Dînî Türk Halk Hikâyelerinden Geyik, Güvercin ve Deve Hikâyeleri -Kaynakları ve Metin Tesisi-. Yüksek Lisans Tezi. İstanbul: Marmara Ü.

DOĞAN, Şaban (2012). "Bir Eski Oğuz Türkçesi Metni Hikâye-i Fâtıma ve Dil Özellikleri”. Akademik Bakış Dergisi (32): 1-20.

KARTALLIOĞLU, Yavuz (2008). "Osmanlı Türkçesindeki Ekler Dudak Uyumuna Göre Nasıl Okunmalıdır?”. Turkish Studies 3 (6): 449-470.

KARTALLIOĞLU, Yavuz (2011). Klasik Osmanlı Türkçesinde Eklerin Ses Düzeni (16, 17 ve 18. Yüzyllar). Ankara: TDK Yay.

KUZUBAŞ, Muhammet (2008). "Manzum Bir Destan Kitabı (Destân-1 Veysel Karânî, Vefât-1 Hz. Fâtıma, Vefât-1 Hz. İbrâhîm, Hikâyet-i Gügercin, Hikâyet-i Geyik)". Uluslararası Sosyal Araştırmalar Dergisi 1 (2): 304-340.

SÖYLEMEZ, Mehmet Mahfuz (2011). Dâstân-ı İbrâhîm Edhem, Dâstân-ı Fâtıma, Dâstân-ı Hâtun. Ankara: Türkiye Diyanet Vakfı Yay. 